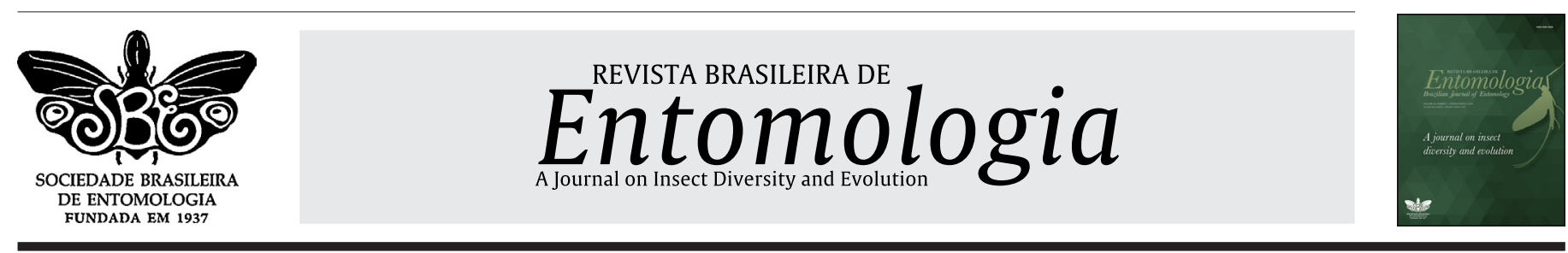

\title{
Morphology of the male reproductive tract in the water scavenger beetle Tropisternus collaris Fabricius, 1775 (Coleoptera: Hydrophilidae)
}

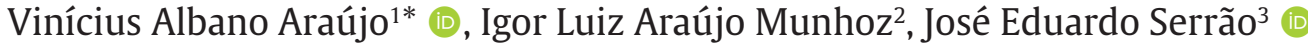 \\ ${ }^{1}$ Universidade Federal do Rio de Janeiro, Instituto de Biodiversidade e Sustentabilidade (NUPEM), Macaé, RJ, Brasil. \\ 2Universidade Federal de Minas Gerais, Belo Horizonte, MG, Brasil. \\ ${ }^{3}$ Universidade Federal de Viçosa, Departamento de Biologia Geral, Viçosa, MG, Brasil.
}

\section{A R T I C L E I N F O}

\section{Article history:}

Received 07 February 2021

Accepted 19 April 2021

Available online 12 May 2021

Associate Editor: Marcela Monné

\section{Keywords:}

Accessory glands

Hydrophilid

Polyphaga

Reproductive system

\begin{abstract}
A B S T R A C T
Members of the Hydrophilidae, one of the largest families of aquatic insects, are potential models for the biomonitoring of freshwater habitats and global climate change. In this study, we describe the morphology of the male reproductive tract in the water scavenger beetle Tropisternus collaris. The reproductive tract in sexually mature males comprised a pair of testes, each with at least 30 follicles, vasa efferentia, vasa deferentia, seminal vesicles, two pairs of accessory glands (a bean-shaped pair and a tubular pair with a forked end), and an ejaculatory duct. Characters such as the number of testicular follicles and accessory glands, as well as their shape, origin, and type of secretion, differ between Coleoptera taxa and have potential to help elucidate reproductive strategies and the evolutionary history of the group.
\end{abstract}

\section{Introduction}

Coleoptera is the most diverse group of insects in the current fauna, with about 400,000 described species and still thousands of new species waiting to be discovered (Slipinski et al., 2011; Kundrata et al., 2019). Beetles have conquered several ecological niches in the terrestrial environment (Toussaint and Short, 2017) and are the most abundant group of aquatic insects, with about 13,000 species, most of them representatives of Dytiscidae and Hydrophilidae (Short, 2018). Coleoptera species richness is greatest in the Neotropical region, particularly in South America (Jach and Balke, 2008; Short, 2018).

Aquatic beetle faunas have been widely sampled in ecological studies focused on biomonitoring and species richness. These relatively large insects are sensitive to environmental changes, show wide distribution, can be easily sampled, and occupy different guilds in aquatic and semiaquatic ecosystems (Short and Fikáček, 2011; Short, 2018). Because of these characteristics, aquatic beetles have been proposed as potential bioindicators of water quality and global climate change impacts (Guareschi et al., 2012; Kaboré et al., 2016).

\footnotetext{
* Corresponding author.

E-mail:vialbano@gmail.com (V.A. Araújo).
}

The evolutionary history of Coleoptera diversity (Lawrence et al., 1995; Lawrence, 2016) has been grounded in phylogenies with characters derived from external and molecular morphology (e.g., Lawrence et al., 2011; Zhang et al., 2018). Although hydropilid form a diverse group it is one of the few families of Polyphaga beetle with robust phylogenetical data (Short and Fikáček, 2013; Nasserzadeh et al., 2017; Toussaint et al., 2017).

The morphology of the reproductive tract and aspects of spermatogenesis have been described in several species of Coleoptera (Sharp, 1912; Happ, 1992), including representatives of Bruchidae (Sigh, 1978; Kasap and Crowson, 1979), Carabidae (Sasakawa, 2007; Hodgson et al., 2013; Kruger et al., 2013; Schubert et al., 2017), Chrysomelidae (Kasap and Crowson, 1979; Wang et al., 2007), Curculionidae (Alzahrani et al., 2013; Wu et al., 2017), Dryophthoridae (Paoli et al., 2014), Scarabaeidae (CarriloRuiz et al., 2008; Martínez and Trotta-Moreu, 2010), Scolytidae (Cerezke, 1964), and Tenebrionidae (Dias et al., 2013, 2015). In Hydrophilidae, a highly diverse family with about 3,100 aquatic species (Madaric et al., 2013; Short and Fikáček, 2013; Nasserzadeh et al. 2017), some studies on different taxa focus on the morphology of internal organs (eg Gundevia 
and Ramamurty, 1977; Bameul, 1996; 1997; Nasserzadeh et al., 2005; Nasserzadeh and Komarek, 2017; Angus et al., 2020; Nasserzadeh, 2020).

Although those studies provide good data about the structure and function of some organs, there are few comparative data from reproductive tract, which might reveal differences between groups, such as presence/absence of structures and shape variations in reproductive organs and spermatozoa (Araújo et al., 2012, 2020, 2021; Paoli et al., 2014; Munhoz et al., 2020; Nasserzadeh, 2020). This study aimed to describe the anatomy and histology of the male reproductive system in the hydrophilid Tropisternus collaris Fabricius, 1775, in order to contribute to the knowledge of reproductive biology and evolutionary history of the Coleoptera.

\section{Material and methods}

Adult males of $T$. collaris $(\mathrm{n}=13$ ) were collected in the Pampulha lagoon (19 $\left.50^{\prime} \mathrm{S} 43^{\circ} 59^{\prime \prime} \mathrm{W}\right)$ in the municipality of Belo Horizonte, state of Minas Gerais, Brazil. The collections were carried out with entomological nets and sieves.

The insects were immobilized at $-5^{\circ} \mathrm{C}$ for $10 \mathrm{~min}$ and the reproductive tract was dissected in sodium cacodylate buffer, $0.1 \mathrm{M}, \mathrm{pH} 7.2$ and transferred to $2.5 \%$ glutaraldehyde in the same buffer for 2 hours at room temperature. Then, the samples were washed in the same buffer, dehydrated in a graded ethanol series (50, 7090 and 95\%) and embedded in historesin (Leica Historesin). Semithin sections ( $2 \mu \mathrm{m}$ thick) were obtained with a glass knife in a rotary microtome (Leica RM 2255 , Germany), stained with $1 \%$ toluidine blue sodium borate, analyzed and photographed with light microscopy (Olympus BX-60, Japan).

\section{Results}

The reproductive tract of sexually mature $T$. collaris males comprised a pair of testes, vasa efferentia, vasa deferentia, seminal vesicles, two pairs of accessory glands ( ag1 = a tubular pair with a forked end; ag2 = a bean-shaped pair), and an ejaculatory duct (Fig. 1A, 1B). Accessory glands and seminal vesicles fused at their extremities, opening into the ejaculatory duct (Fig. 1A).

Testes had a pectinate shape and contained at least 30 follicles each (Figs. 1A, 2A). Spermatozoa moved in bundles from testicular follicles through the short vas efferens into the vas deferens, where bundles were dissociated (Fig. 2A, 2B). Testis follicles showed cells at three different stages of spermatogenesis (Fig. 2A-D). The growth zone was characterized by groups of spermatogonia forming cysts, the maturation zone contained sperm bundles (Fig. 2C), and the differentiation zone comprised elongated spermatids and spermatozoa (Fig. 2D).

Tubular accessory glands (ag1) were parallel to the vas deferens in the vicinity of the bean-shaped accessory gland (ag2) (Fig. 3A, 3B). The vas deferens was dilated near the glandular region, opening into a seminal vesicle, which showed the lumen filled with spermatozoa, a simple squamous epithelium, and an external muscle layer (Fig. 3C, 3D). Tubular accessory glands were composed of a single epithelial layer (Fig. 4A). The most distal portion of the tubular gland (ag1) showed a prismatic epithelium and apocrine-type secretion with many granules in the lumen (Fig. 4B, 4C). Bean-shaped accessory glands (ag2) had a folded wall with a monolayered prismatic epithelium and lumen full of granular secretion (Figs. 3A, 3B, 4A, 4B). The region of the beanshaped gland (ag2) where cisternae were found was lined with thick muscle fibers (Figs. 3A, 4A, 4B). Near the center of the bean-shaped gland (ag2), tubular accessory glands (ag1) and vasa deferentia fused and opened into the ejaculatory duct (Figs. 4A, 4B, 5A).

The ejaculatory duct was long and dilated in the median region, formed by simple cuboidal epithelium with basal nuclei, lined internally by a thin cuticle and externally by several layers of longitudinal and circular muscles (Fig. 5B, 5C).

\section{Discussion}

The anatomy of the reproductive tract of $T$. collaris is similar to that of most Coleoptera families, which, in general, is composed of testes, vasa deferentia, a pair of seminal vesicles, and a single ejaculatory duct, varying mainly in the number of testicular follicles and type of accessory glands (Cerezke, 1964; Nasserzadeh et al., 2005; Dias et al., 2013; Kruger et al., 2013; Paoli et al., 2014; Schubert et al., 2017; Wu et al., 2017; Nasserzadeh, 2020). For beetles, the morphological characters from reproductive tract are potential sources for phylogenetical hypotheses in higher taxa (Dettner et al., 1986; Opitz, 2014; Nasserzadeh, 2020). In fact, Imms (1964) investigated characters derived from testicular morphology and identified two general anatomical patterns of the male reproductive tract in the two largest suborders of Coleoptera, Adephaga and Polyphaga. In Adephaga, testes are composed of a singular, spiral follicle surrounded by a conjunctive capsule (Will et al., 2005; SasaKawa,

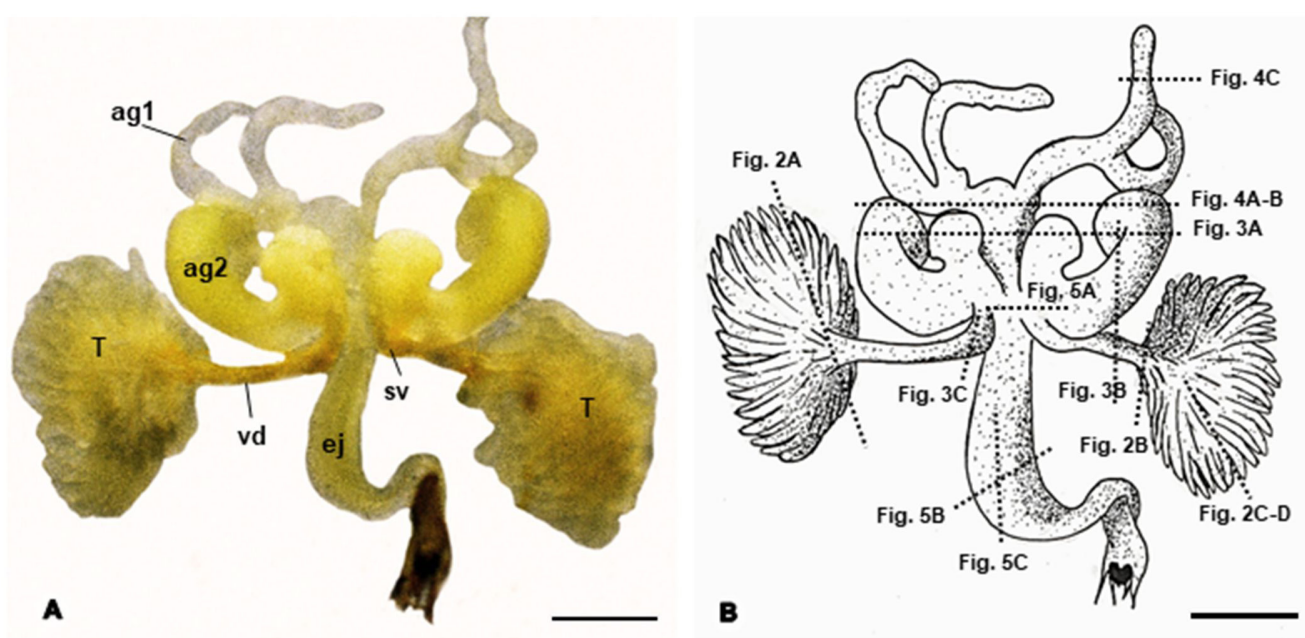

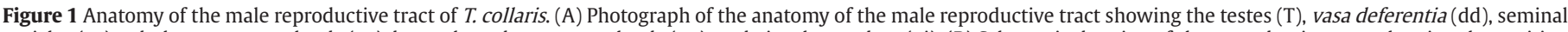

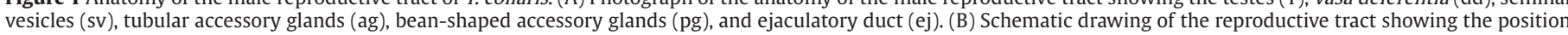
and direction of histological sections presented in Figures 2-5. Bars: $0.4 \mathrm{~cm}$. 


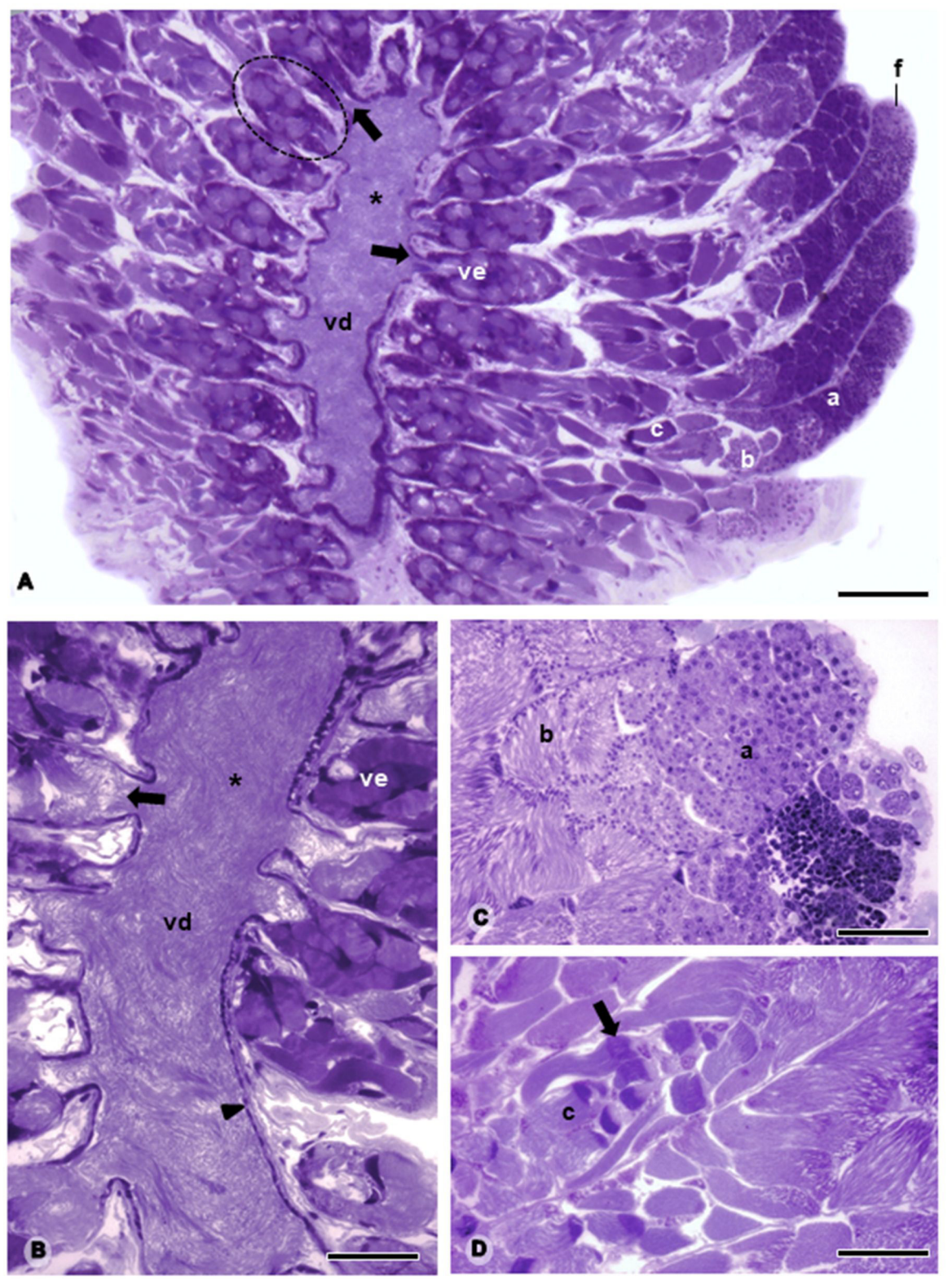

Figure 2 Histology of the male reproductive tract of T. collaris. (A) Longitudinal section of a testis showing the follicles (f); growth (a), maturation (b), and differentiation (c) zones; and vas efferens (ve) opening (arrow) into a vas deferens (vd) with lumen full of spermatozoa (asterisk). (B) Longitudinal section showing detail of the vasa efferentia (ve) in the confluence zone (black arrow) with the vas deferens (vd). The white arrow points to sperm bundles in the vas efferens. The asterisk indicates the lumen of a vas deferens with dissociated bundles. The arrowhead points to the epithelial of the vas deferens. (C and D) Details of the stages of spermatogenesis, showing zones of cell growth (a), maturation (b), and differentiation (c). The arrow points to a sperm bundle. Bars: $A$ and $B=600 \mu \mathrm{m}, \mathrm{C}$ and $\mathrm{D}=200 \mu \mathrm{m}$.

2007; Schubert et al., 2017). In Polyphaga, the number of testicular follicles varies, even within families: 6-60 in Tenebrionidae (Doyen and Tschinkel, 1982; Dias et al., 2013), 6 in Geotrupidae (Martínez and Trotta-Moreu, 2010) and Scarabaeidae (Carrilo-Ruiz et al., 2008), 8-20 in Curculionoidea (Calder, 1990; Goldson and Emberson 2012; Wu et al., 2017), 20 in Chrysomelidae (Simões, 2012), and 50-60 in Dryophthoridae (Paoli et al., 2014). In T. collaris adults, each testis contained at least 30 follicles and cells at different stages of spermatogenesis, indicating continuous sperm production, a common characteristic of insects that copulate several times during adulthood (Moreira et al., 2008; Wu et al., 2017; Munhoz et al., 2020).

In Hydrophilinae, morphological differences in the testes were reported among genera (Nasserzadeh, 2020). The accessory gland (ag2) size was used as a feature for the testis size. In this sense, in the representatives of Hydrochara and Hidrophilus, the testes are smaller than the accessory gland (ag2). However, in Hydrochara the testis follicles are distinguishable, short and narrowed, whereas in Hydrophilus the testes are compact and bean-shaped and the follicles are hard to be distinguished. Testes larger or equal to the accessory gland (ag2) occur in Hydrobius fusciceps and in Sternolophus testis, the latter similar to here observed for $T$. collaris, in which the testis follicles are tubular and clustered. Short et al. (2017) have pointed out that Tropisternus as a sister group of Sternolophus, which may be supported by similar testis morphology between the closely related genera of Hydrophilini.

As in T. collaris (Hydrophilidae), the seminal vesicles are well developed in other Coleoptera, including the curculionoid families (Calder, 1990; Hoffman and Raffa, 1992; Goldson and Emberson, 2012; Wu et al., 2017), and Carabidae (Schubert et al., 2017). However, males of Rhynchophorus ferrugineus Heyne, A.-Taschenberg \& O., 1908 (Dryophthoridae) do 


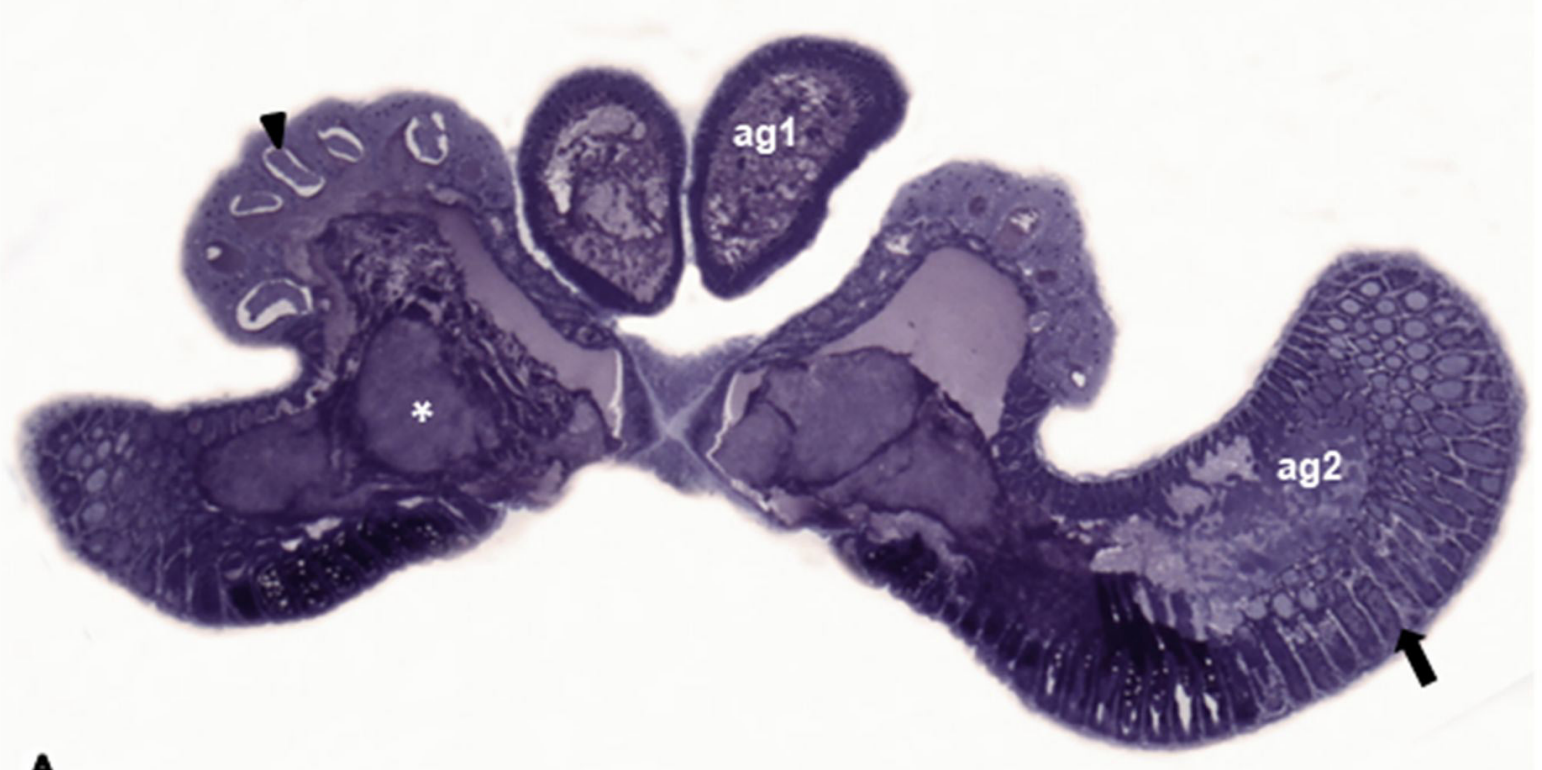

A
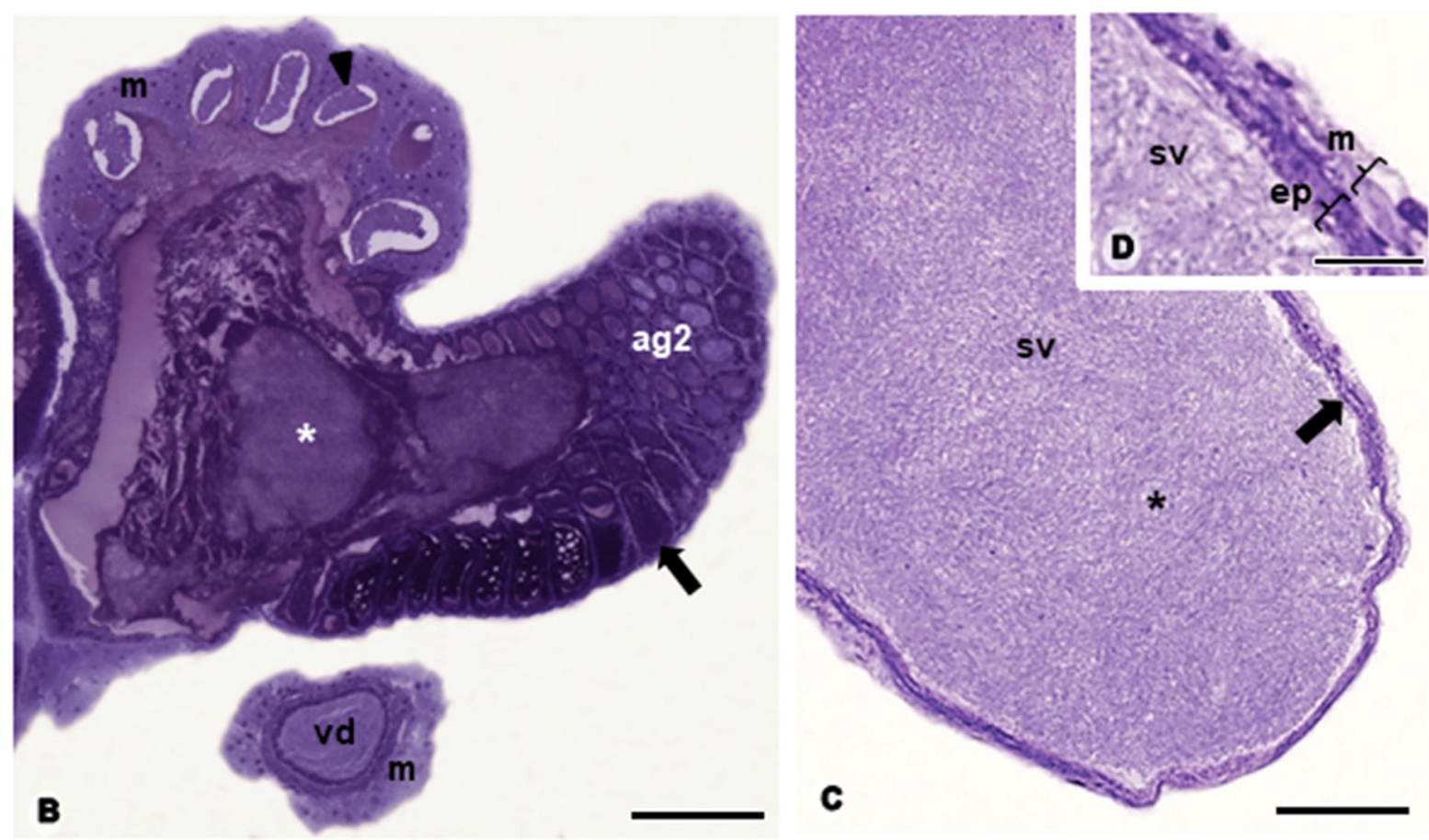

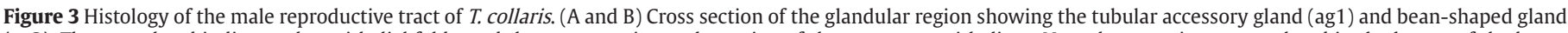

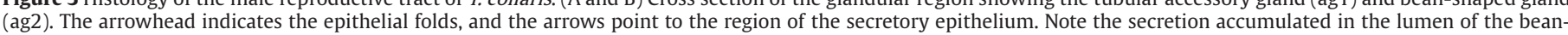

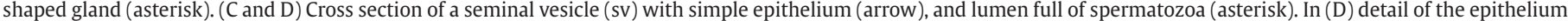
(ep) and the external muscular layer (m). Bars: $A=200 \mu \mathrm{m}, B$ and $C=100 \mu \mathrm{m}, \mathrm{D}=25 \mu \mathrm{m}$.

not have a typical seminal vesicle, a large number of spermatozoa can be found in the proximal region of vasa deferentia (Paoli et al., 2014).

We observed two pairs of accessory glands in T. collaris. The number varies among Coleoptera families, being used as an auxiliary character in the taxonomy of Bruchidae (Sigh, 1978). Scarabaeidae males have a pair of accessory glands (Carrilo-Ruiz et al., 2008) and Curculionidae, one or two pairs (Burke, 1959; Cerezke, 1964; Wu et al., 2017). Tubular accessory glands (ag1), such as those found in T. collaris, are common in many coleopterans (Kaulenas, 1992), including Chrysomelidae (Anderson, 1950), Scarabaeidae (De Loof and Lagasse, 1972), Cleridae,
Carabidae (Opitz, 2003), and Dryophthoridae (Paoli et al., 2014). In addition to tubular accessory glands (ag1), T. collaris has a pair of bean-shaped glands (ag2), as also described in Hydrochara spp. (Nasserzadeh et al., 2005). In Hydrochara ssp., the bean-shaped gland (ag2) contains individual globules, where secretions are produced and stored (Nasserzadeh et al., 2005). Such secretions are mainly associated with sperm maintenance and activation, induction and acceleration of oviposition in females, spermatophore formation, and mechanisms to ensure fidelity, such as formation of a barrier to prevent further mating (Chen, 1984; Gillott, 2003; King et al., 2011; Polat et al., 2020). 


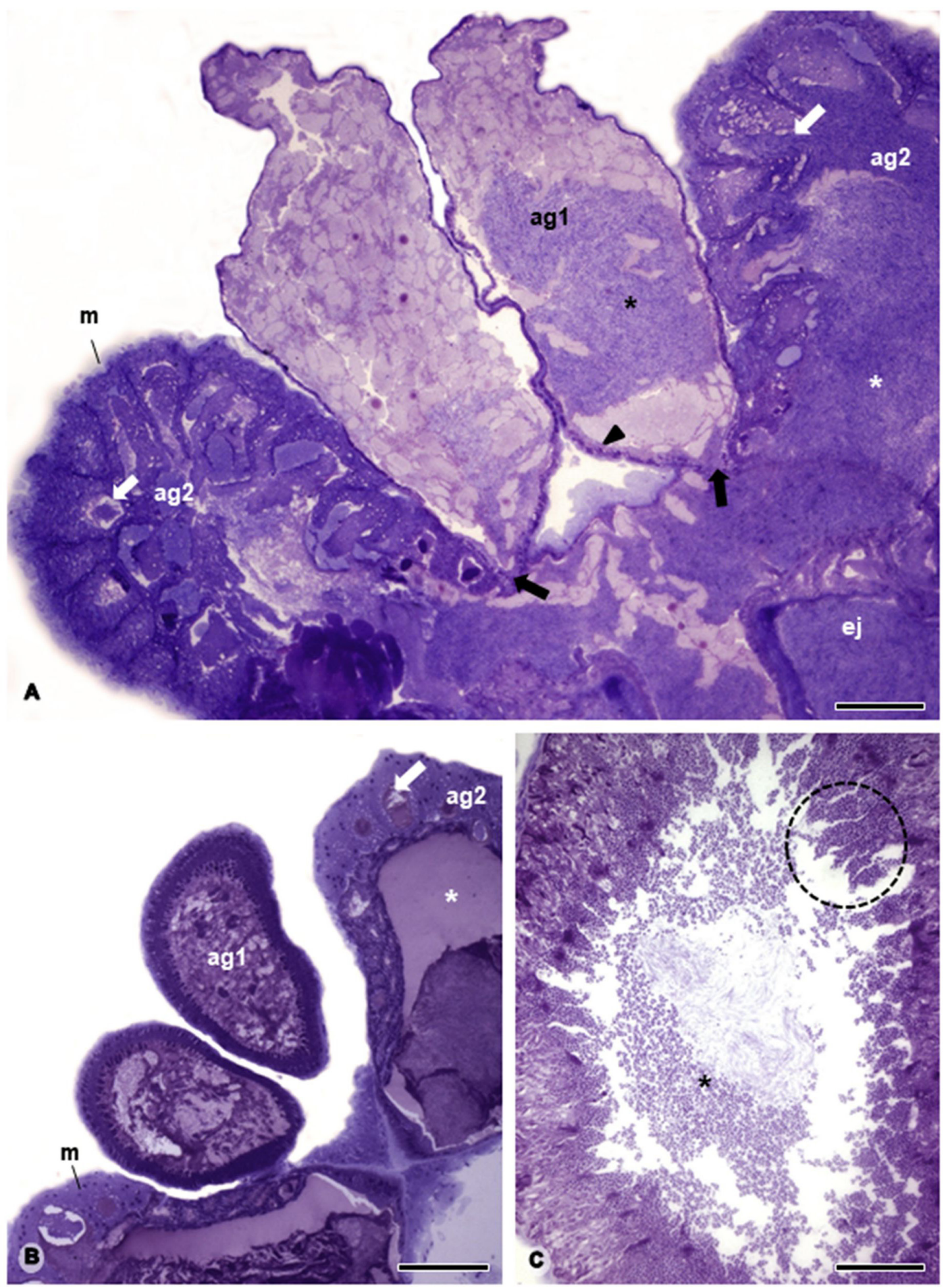

Figure 4 Histology of the male reproductive tract of T. collaris. (A and B) Longitudinal section of the glandular region showing a tubular gland (ag1) with lumen full of secretion (black asterisk). The arrowhead points to the nucleus of the epithelium, and the black arrows to the opening of the common duct into the bean-shaped gland (ag2) in a region that precedes the ejaculatory duct (ej). Note the multilobed secretion (white arrow), lumen with secretion (white asterisk), and muscle layer ( $\mathrm{m}$ ) of the bean-shaped gland (ag2). (C) Cross section of the apical portion of the tubular gland showing apocrine secretion (dashed circle) and secretion granules in the lumen (asterisk). Longitudinal section of the ejaculatory duct (ej) showing the lumen (asterisk), simple cuboidal epithelium (arrow), and thick muscle layer (m). Bars: $A=200 \mu \mathrm{m}, B=150 \mu \mathrm{m}$, and C = $100 \mu \mathrm{m}$.

Like most insects, $T$. collaris has a single, median ejaculatory duct covered by a cuticle, evidence of its ectodermal origin (Bushrow et al., 2006; Araújo et al., 2010). The cuticle helps stabilize the duct against the action of intrinsic muscles during ejaculation. The dilated region in the median portion of the ejaculatory duct appears to be where spermatozoa are pumped to the female bursa copulatrix through the action of a strong muscle sheath surrounding the duct epithelial wall (Nasserzadeh et al., 2005; Wu et al., 2017).

In this study, we described the anatomy and histology of the male reproductive tract of $T$. collaris. The size and shape of the testis, number of testis follicles and accessory glands have differences between the species of the tribe already studied. These results may contribute to 

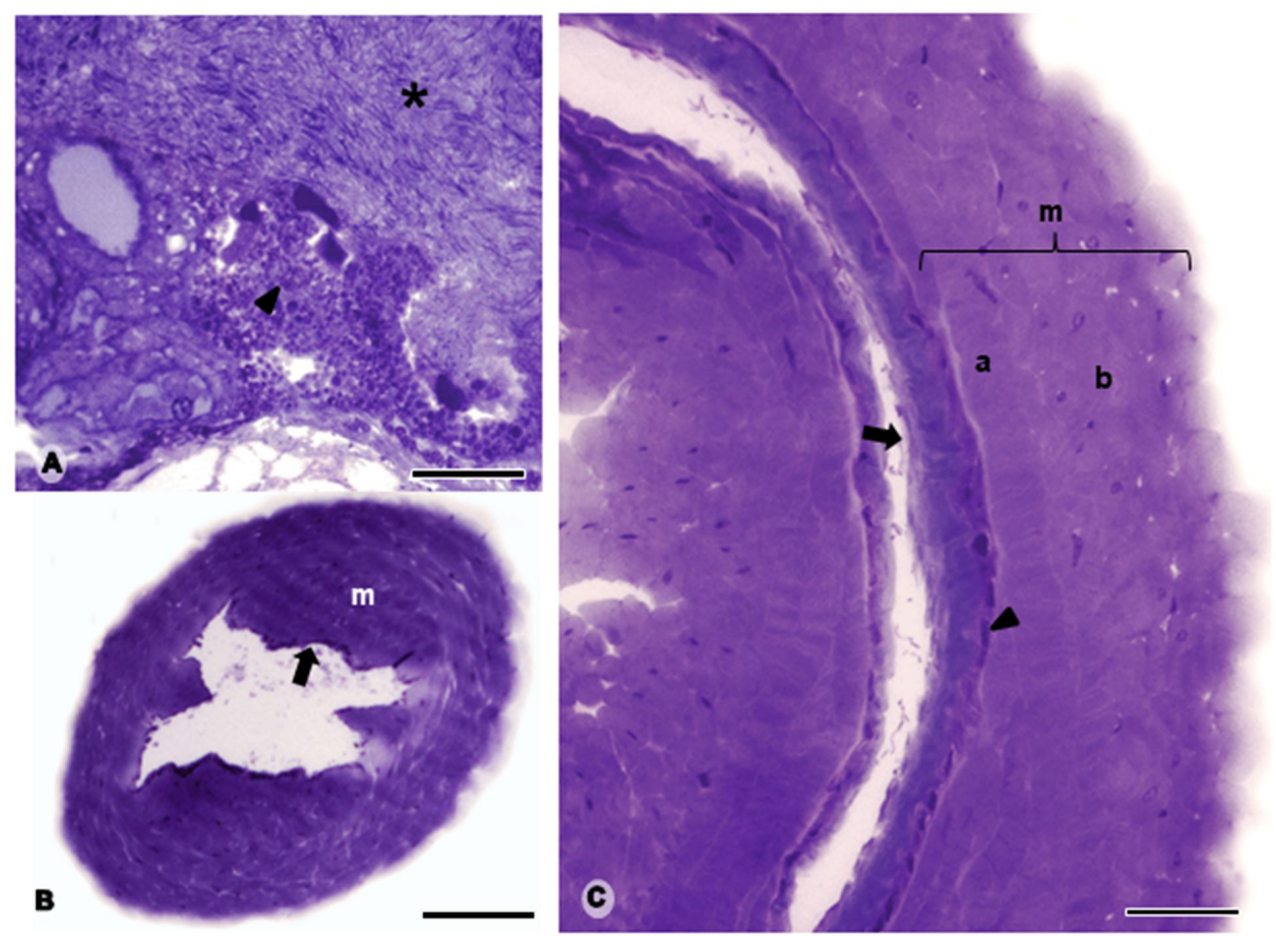

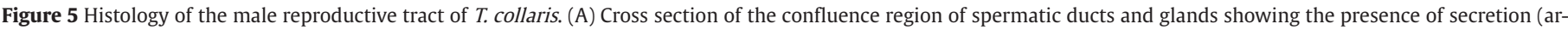

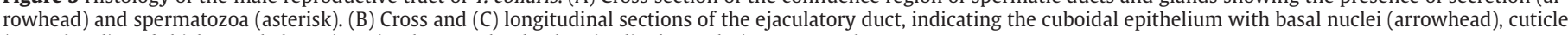
(arrowhead), and thick muscle layer ( $\mathrm{a}=$ circular muscles, $\mathrm{b}=$ longitudinal muscles). Bars: $\mathrm{A}$ and $\mathrm{B}=200 \mu \mathrm{m}, \mathrm{C}=400 \mu \mathrm{m}$.

elucidating reproductive strategies in Hydrophilidae and the evolutionary history of aquatic Coleoptera.

\section{Acknowledgements}

The authors thank Dr. Nelson Ferreira Jr., Department of Zoology, Federal University of Rio de Janeiro, Brazil, for the kindness and immediate assistance with confirmation in identifying bug species.

\section{Conflicts of interest}

The authors declare no conflict of interest.

\section{Author contribution statement}

VAA and ILAM conceived the research, dissections, photographs and the reproductive morphology work. ILAM realized illustrations and VAA the preparation of plates. VAA and JES improved the introduction, results and discussion of the document. All authors participated in the final redaction and critically reviewed the manuscript and accepted the final version of the paper.

\section{References}

Alzahrani, A. M., Abdelsalam, A. S., Elmenshawy, O. M., Abdel-Moneim, A. M., 2013. Ultrastructural characteristics of spermiogenesis in Rhynchophorus ferrugineus (Coleoptera: curculionidae). Fla. Entomol. 96, 1463-1469. https://doi.org/10.1653/024.096.0426.

Anderson, J. M., 1950. A cytological and cytochemical study of the male accessory reproductive glands in the japanese beetle, Popillia japonica Newman. Biol. Bull. 99, 49-64. https://doi.org/10.2307/1538751.
Angus, R.B., Sadílek, D., Shaarawi, F., Dollimore, H., Liu, H.-C., Seidel, M., Sýkora, V., Fikáček, M., 2020. Karyotypes of water scavenger beetles (Coleoptera: Hydrophilidae): new data and review of published records. Zool. J. Linn. Soc. XX, 1-40. https://doi.org/10.1093/ zoolinnean/zlaa105.

Araújo, V. A., Moreira, J., Lino-Neto, J., 2010. Morphology of the male reproductive system of the social wasp, Polistes versicolor versicolor, with phylogenetic implications. J. Insect Sci. 10, 1-10. https://doi. org/10.1673/031.010.7101.

Araújo, V. A., Serrão, J. E., Moreira, J., Báo, S. N., Lino-Neto, J., 2012. Ultrastructure of spermatozoa in two solitary bee species with an emphasis on synapomorphic traits shared in the family Apidae. Microsc. Res. Tech. 75, 74-80. https://doi.org/10.1002/jemt.21027.

Araújo, V. A., Bacca, T., Dias, L., 2020. Anatomy of male and female reproductive organs of stink bugs pests (Pentatomidae: Heteroptera) from soybean and rice crops. Biota Neotrop. 20 (4), e20201045. https://doi.org/10.1590/1676-0611-BN-2020-1045.

Araújo, V. A., Bacca, T., Días, G. L., 2021. Histología del tracto reproductor masculino del chinche depredador Zelus longipes (Heteroptera: Reduviidae). Caldasia. 43 (1), 39-48. https://dx.doi.org/10.15446/ caldasia.v43n1.85745.

Bameul, F., 1996. A new Hydrochara Berthold from North Korea (Coleoptera: hydrophilidae). Nouv. Rev. Entomol. 13, 3-11.

Bameul, F., 1997. A revision of Protosternum Sharp (Coleoptera: hydrophilidae). Nouv. Rev. Entomol. 14, 17-41.

Burke, H. R., 1959. Morphology of the reproductive systems of the cotton boll weevil (Coleoptera: curculionidae). Ann. Entomol. Soc. Am. 52 , 287-294. https://doi.org/10.1093/aesa/52.3.287.

Bushrow, E. S., Fuller, C. L., Cowan, D. P., Byrd, C. A., 2006. Anatomy of the male reproductive system and sperm morphology in the caterpillar-hunting wasp Ancistrocerus antilope (Hymenoptera, Vespidae). Invertebr. Biol. 125, 354-362. https://doi.org/10.1111/j.17447410.2006.00067.x. 
Calder, A. A., 1990. Gross morphology of the soft parts of the male and female reproductive systems of Curculionoidea (Coleoptera). J. Nat. Hist. 24, 453-505. https://doi.org/10.1080/00222939000770341.

Carrilo-Ruiz, H., Martínez, I., Morón, M. A., 2008. Comparative study of the reproductive system of two species of Hoplia (Coleoptera: Scarabaeidae: Hoplinae). Proc. Entomol. Soc. Wash. 110, 778-788. https://doi.org/10.4289/07-052.1.

Cerezke, H. F., 1964. The morphology and functions of the reproductive systems of Dendroctonus monticolaeHopk. (Coleoptera: scolytidae). Can. Entomol. 96, 477-500. https://doi.org/10.4039/Ent96477-3.

Chen, P. S., 1984. The functional morphological and biochemistry of insect male accessory glands and their secretions. Annu. Rev. Entomol. 29, 233-255. https://doi.org/10.1146/annurev.en.29.010184.001313.

De Loof, A., Lagasse, A., 1972. The ultrastructure of the male accessory reproductive glands of the colorado beetle. Z. Zellforsch. Mikrosk. Anat. 130, 545-552. https://doi.org/10.1007/BF00307006.

Dettner, K., Hübner, M., Classen, R., 1986. Age structure, phylogeny and prey of some Rheophilic Dytiscidae (Coleoptera). Entomol. Basil. 11, 343-370.

Dias, G. D., Oliveira, C. M., Lino-Neto, J., 2013. Testicular and spermatogenic characteristics of Lagria villosa (Tenebrionidae: Lagriinae) with taxonomic inferences. Tissue Cell 45, 227-230. https://doi. org/10.1016/j.tice.2013.03.006.

Dias, G., Lino-Neto, J., Mercati, D., Dallai, R., 2015. The sperm ultrastructure and spermiogenesis of Tribolium castaneum(Coleoptera: Tenebrionidae) with evidence of cyst degeneration. Micron 73, 21-27. https://doi. org/10.1016/j.micron.2015.03.003.

Doyen, J. T., Tschinkel, W. R., 1982. Phenetic and cladistic relationships among tenebrionid beetles (Coleoptera). Syst. Entomol. 7, 127-183. https://doi.org/10.1111/j.1365-3113.1982.tb00129.x.

Gillott, C., 2003. Male accessory gland secretions: modulators of female reproductive physiology and behavior. Annu. Rev. Entomol. 48, 163-184. https://doi.org/10.1146/annurev.ento.48.091801.112657.

Goldson, S. L., Emberson, R. M., 2012. Reproductive morphology of the Argentine stem weevil, Hyperodes bonariensis (Coleoptera: curculionidae). N. Z. J. Zool. 8, 67-77. https://doi.org/10.1080/030 14223.1981.10427942.

Guareschi, S., Gutiérrez-Cánovas, C., Picazo, F., Sánchez-Fernández, D., Abellán, P., Velasco, J., Millán, A., 2012. Aquatic macroinvertebrate biodiversity: patterns and surrogates in mountainous Spanish national parks. Aquat. Conserv. 22, 598-615. https://doi.org/10.1002/aqc.2256.

Gundevia, H. S., Ramamurty, P. S., 1977. The male accessory reproductive glands and spermatophore in Hydrophilus olivaceus (PolyphagaColeoptera). Z. Mikrosk. Anat. Forsch. 91, 475-492.

Happ, G. M., 1992. Maturation of the male reproductive system and its endocrine regulation. Annu. Rev. Entomol. 37, 303-320. https://doi. org/10.1146/annurev.en.37.010192.001511.

Hodgson, A. N., Ferenz, H. J., Schneider, S., 2013. Formation of sperm bundles in Pterostichus nigrita (Coleoptera: carabidae). Invertebr. Reprod. Dev. 57, 120-131. https://doi.org/10.1080/07924259.2012 .695295 .

Hoffman, G. D., Raffa, K. F., 1992. Maturation of the male pales weevil (Coleoptera: Curculionidae) reproductive system and its effect on male response to females. Ann. Entomol. Soc. Am. 85, 571-577. https://doi.org/10.1093/aesa/85.5.571.

Imms, A. D., 1964. A general textbook of entomology, including the anatomy, physiology, development and classification of insects. Methuen \& Co Ltd., London.

Jach, M. A., Balke, M., 2008. Global diversity of water beetles (Coleoptera) in freshwater. Hydrobiologia 595, 419-442. https://doi.org/10.1007/9781-4020-8259-7_43.
Kaboré, I., Jäch, M. A., Ouéda, A., Moog, O., Guenda, W., Melcher, A. H., 2016. Dytiscidae, Noteridae and Hydrophilidae of semi-arid rivers and reservoirs of Burkina Faso: species inventory, diversity and ecological notes. J. Biodivers. Environ. Sci. 8, 1-14.

Kasap, H. K., Crowson, R. A., 1979. The male reproductive organs of Bruchidae and Chrysomelidae (Coleoptera). Turk Bit Kor Derg. 3, 199-216.

Kaulenas, M. S., 1992. Insect accessory reproductive structures: Function, structure and development. Springer Verlag, Berlin.

King, M., Eubel, H., Millar, H., Baer, B., 2011. Proteins within the seminal fluid are crucial to keep sperm viable in the honeybee Apis mellifera. J. Insect Physiol. 57, 409-414. https://doi.org/10.1016/j. jinsphys.2010.12.011.

Kruger, S., Ferenz, H. J., Randall, M., Hodgson, A. N., 2013. Structure of the male reproductive accessory glands of Pterostichus nigrita (Coleoptera: Carabidae), their role in spermatophore formation. Invertebr. Reprod. Dev. 58, 75-88. https://doi.org/10.1080/07924 259.2013.822835.

Kundrata, R., Blank, S. M., Prosvirov, A. S., Sormova, E., Gimmel, M. L., Vondráček, D., Kramp, K., 2019. One less mystery in Coleoptera systematics: the position of Cydistinae (Elateriformia incertae sedis) resolved by multigene phylogenetic analysis. Zool. J. Linn. Soc. 187, 1259-1277. https://doi.org/10.1093/zoolinnean/zlz104.

Lawrence, J. F., Slipinski, S. A., Pakaluk, J., 1995. From Latreille to Crowson: a history of the higher-level classification of beetles. In: Pakaluk, J., Slipinski, S.N. (Eds.), Biology, phylogeny, and classification of Coleoptera, Muzeum i Instytut Zoologii PAN, Warsaw, pp. 87-154.

Lawrence, J. F., Slipinski, A., Seago, A. E., Thayer, M. K., Newton, A. F., Marvaldi, A. E., 2011. Phylogeny of the Coleoptera based on morphological characters of adults and larvae. Ann. Zool. 61, 1-217. https://doi.org/10.3161/000345411X576725.

Lawrence, J. F. 2016. Classification (families \& subfamilies). In: Beutel, R.G., Leschen, R.A.B. (Eds.), Handbook of zoology, Arthropoda: Insecta: Coleoptera, beetles, Vol. 1: morphology and systematics (Archostemata, Adephaga, Myxophaga, Polyphaga, 2. ed. Walter de Gruyter, Berlin, pp. 13-22.

Madaric, B. B., Stankovic, V. M., Corak, L., Ugarkovic, D., Komarek, A., 2013. Contributions to molecular systematics of water scavenger beetles (Hydrophilidae, Coleoptera). J. Zool. Syst. Evol. Res. 51, 165171. https://doi.org/10.1111/jzs.12013.

Martínez, I. M., Trotta-Moreu, N., 2010. Comparative study of mexican Geotrupini (Coleoptera: Scarabaeoidea: Geotrupidae) Reproductive systems, with taxonomic commentaries. Coleopt. Bull. 64, 129-140. https://doi.org/10.1649/072.064.0209.

Moreira, P. A., Araújo, V. A., Zama, U., Lino-Neto, J., 2008. Morphology of male reproductive system in three species of Trypoxylon(Trypargilum) Richards (Hymenoptera: crabronidae). Neotrop. Entomol. 37, 429435. https://doi.org/10.1590/S1519-566X2008000400012.

Munhoz, I. L. A., Serrão, J. E., Dias, G., Melo, A. L., Araújo, V. A., 2020. Anatomy and histology of the male reproductive tract in giant water bugs of the genus Belostoma Latreille, 1807 (Heteroptera, Belostomatidae). Int. J. Trop. Insect Sci. 40, 1608-1614. https://doi. org/10.1007/s42690-020-00207-7.

Nasserzadeh, H., Hosseinie, S., Monsefi, M., 2005. Morphology of the reproductive systems of the Iranian species of Hydrochara Berthold (Coleoptera: hydrophilidae). Koleopterol. Rundsch. 75, 227-245.

Nasserzadeh, H., 2020. Comparative morphological study of the genital tube in some hydrophilid species (Coleoptera: Hydrophilidae) with a discussion on the importance of the internal genital characters in phylogenetic studies. Journal of Entomological Society of Iran. 40(2), 201-227. https://doi.org/10.22117/jesi.2020.351817.1395. 
Nasserzadeh, H., Alipanah, H., Gilasian, E., 2017. Phylogenetic study of the genus Sternolophus Solier (Coleoptera, Hydrophilidae) based on adult morphology. ZooKeys 712, 69-85.

Nasserzadeh, H., Komarek, A., 2017. Taxonomic revision of the water scavenger beetle genus Sternolophus Solier, 1834 (Coleoptera: hydrophilidae). Zootaxa 4282 (2), 201-254.

Opitz, W., 2003. Spermatophores and spermatophore producing internal organs of Cleridae (Coleoptera: Clerinae): Their biological and phylogenetic implications. Coleopt. Bull. 57, 167-190. https://doi. org/10.1649/0010-065X(2003)057[0167:SSPIOO]2.0.CO;2.

Opitz, W., 2014. Morphologic studies of the alimentary canal and internal reproductive organs of the Chaetosomatidae and the Cleridae (Coleoptera: Cleroidea) with comparative morphology and taxonomic analyses" (2014). Insecta Mundi 0342, 1-40.

Paoli, F., Dallai, R., Cristofaro, M., Arnone, S., Francardi, V., Roversi, P. F., 2014. Morphology of the male reproductive system, sperm ultrastructure and y-irradiation of the red palm weevil Rhynchophorus ferrugineus Oliv. (Coleoptera: dryophthoridae). Tissue Cell 46, 274-285. https:// doi.org/10.1016/j.tice.2014.06.003.

Polat, I., Mutlu, D. A., Suludere, Z., 2020. Accessory glands of male reproductive system in Pseudochorthippus parallelus parallelus (Zetterstedt, 1821) (Orthoptera; Acrididade): A light and electron microscopic study. Microsc. Res. Tech. 83, 232-238. https://doi. org/10.1002/jemt.23406.

Sasakawa, K., 2007. Sperm bundle and reproductive organs of carabid beetles tribe Pterostichini (Coleoptera: carabidae). Sci. Nat. 94, 384-391. https://doi.org/10.1007/s00114-006-0200-4.

Schubert, L. F., Krüger, S., Moritz, G. B., Schubert, V., 2017. Male reproductive system and spermatogenesis of Limodromus assimilis (Paykull 1790). PLoS One 12, e0180492. https://doi.org/10.1371/ journal.pone.0180492.

Sharp, D., 1912. The comparative anatomy of the male genital tube in Coleoptera. Transactions of the Entomological Society of London, London.

Short, A., Fikáček, M., 2011. World catalogue of the Hydrophiloidea (Coleoptera): additions and corrections II (2006-2010). Acta Entomol. Mus. Natl. Pragae 51, 83-122. https://doi.org/10.1111/syen.12024.

Short, A., Fikáček, M., 2013. Molecular phylogeny, evolution and classification of the Hydrophilidae (Coleoptera). Syst. Entomol. 38, 723-752.
Short, A. E. Z., Cole, J., Toussaint, E. F. A., 2017. Phylogeny, classification and evolution of the water scavenger beetle tribe Hydrobiusini inferred from morphology and molecules (Coleoptera: Hydrophilidae: Hydrophilinae). Syst. Entomol. 42, 677-691.

Short, A. E. Z., 2018. Systematics of aquatic beetles (Coleoptera): current state and future directions. Syst. Entomol. 43, 1-18.

Sigh, T., 1978. The male accessory glands in Bruchidae (Coleoptera) and their taxonomic significance. Scand. Entomol. 9, 198-203. https:// doi.org/10.1163/187631278X00449.

Simões, M., 2012. Male and female reproductive systems of Stolas conspersa (Germar) (Coleoptera, Chrysomelidae, Cassidinae). Rev. Bras. Entomol. 56, 19-22. https://doi.org/10.1590/S008556262012005000007.

Slipinski, S. A., Leschen, R. A. B., Lawrence, J. F., 2011. Order Coleoptera Linnaeus, 1758. In: Zhang, Z.Q. (Ed.), Animal biodiversity: an outline of higher-level classification and survey of taxonomic richness. Magnolia Press, Auckland, New Zealand. pp. 203-208.

Toussaint, E. F. A., Short, A. E. Z., 2017. Biogeographic mirages? Molecular evidence for dispersal-driven evolution in Hydrobiusini water scavenger beetles. Syst. Entomol. 42, 692-702. https://doi. org/10.1111/syen.12237.

Wang, X. P., Zhou, X. M., Wang, Y. Y., Lei, C. L., 2007. Internal reproductive system and diapausing morphology of the Brassica leaf beetle Phaedon brassicae Baly (Coleoptera: Chrysomelidae: Chrysomelinae). Coleopt. Bull. 61, 457-462. https://doi.org/10.1649/0010-065X(200 7)61[457:IRSADM]2.0.CO;2.

Will, K. W., Liebherr, J. K., Maddison, D. R., Galian, J., 2005. Absence asymmetry: the evolution of monorchid beetles (Insecta: Coleoptera: Carabidae).J. Morphol. 264, 75-93. https://doi.org/10.1002/jmor.10319.

Wu, Y. F., Wei, L. S., Torres, M. A., Zhang, X., Wu, S. P., Chen, H., 2017. Morphology of the male reproductive system and spermiogenesis of Dendroctonus armandi Tsai and Li (Coleoptera: Curculionidae: Scolytinae). J. Insect Sci. 17, 1-9. https://doi.org/10.1093/jisesa/iew116.

Zhang, S.Q., Che, L.H., Li, Y., Dan, L., Pang, H., Ślipiński, A., Zhang, P., 2018. Evolutionary history of Coleoptera revealed by extensive sampling of genes and species. Nat. Commun. 9, 1-11. https://doi. org/10.1038/s41467-017-02644-4. 